\title{
Effect of endodontic preflaring on electronic determination of working length
}

\author{
Efeito do pré-alargamento endodôntico na determinação \\ eletrônica do comprimento de trabalho
}

\section{Abstract}

Purpose: To evaluate the effect of preflaring on the electronic measurement of working length in mesiobuccal roots of maxillary molars.

Methods: Thirty roots were embedded in an alginate model. Root canals were irrigated with $2.5 \%$ sodium hypochlorite, and a size $10 \mathrm{~K}$ file was inserted into the canal until the locator indicated that apical constriction had been reached. Then, the cervical portion of each canal was flared using the ProTaper system shaping files, whereupon electronic measurements were carried out again.

Results: The Student's $t$ test for paired samples did not reveal statistically significant differences in the measurements obtained for preflared and unflared canals $(P<0.05)$.

Conclusion: Based on the lack of clinical significant relevance of the comparisons carried out in the present study, it is possible to conclude that electronic working length measurement can be carried out either before or after cervical preparation.

Key words: Root canal preparation; Endodontics; tooth apex

\section{Resumo}

Objetivo: Avaliar o efeito do pré-alargamento sobre a medição eletrônica do comprimento de trabalho em raízes mésio-vestibulares de molares superiores.

Metodologia: Trinta raízes foram incluídas em um modelo de alginato. Canais radiculares foram irrigados com hipoclorito de sódio a 2,5\%, e uma lima de tamanho $10 \mathrm{~K}$ foi inserida no canal até onde o localizador indicou que a constrição apical tinha sido alcançada. A porção cervical de cada canal foi alargada usando as limas do sistema ProTaper, quando então as medições eletrônicas foram realizados novamente.

Resultados: $O$ teste t de Student para amostras pareadas não mostrou diferenças estatisticamente significativas nas medições obtidas para canais pré-alargados e não alargados $(P<0,05)$.

Conclusão: Com base na falta de relevância clínica significativa das comparações realizadas no presente estudo, é possível concluir que a medição do comprimento eletrônico de trabalho pode ser realizado antes ou após o preparo cervical.

Palavras-chave: Preparo do canal radicular; endodontia; ápice

\section{Fernanda Ullmann Lopez a Fernando Branco Barletta ${ }^{b}$ \\ Vânia Regina Camargo Fontanella a Fabiana Soares Grecca a}

\begin{abstract}
- Department of Conservative Dentistry, School of Dentistry, Universidade Federal do Rio Grande do Sul (UFRGS), Porto Alegre, RS, Brazil

b Department of Conservative Dentistry, School of Dentistry, Universidade Luterana do Brasil (ULBRA), Canoas, RS, Brazil
\end{abstract}

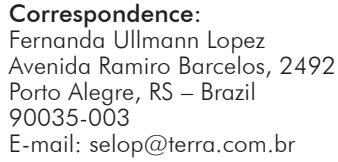

Conflict of Interest Statement: The authors state that there are no financial and personal conflicts of interest that could have inappropriately influenced their work.

Copyright: (C) 2011 Lopez et al.; licensee EDIPUCRS This is an Open Access article distributed under the terms of the Creative Commons AttributionNoncommercial-No Derivative Works 3.0 Unported License. 


\section{Introduction}

Correct determination of working length (WL) is a critical requirement for the success of endodontic therapy, and it has been stated that the WL for instrumentation and obturation of the root canal system should be established at the apical constriction or minor foramen(1). When instrumentation is carried out without reaching the WL, part of the root canal remains inappropriately cleaned and shaped. On the other hand, when the procedure exceeds the WL, periapical tissues are damaged, and an inflammatory process occurs (2).

Electronic apex locators (EALs) have been introduced in endodontics with the aim of improving one of the most important endodontic processes: the determination of WL for the subsequent obturation of root canals. The specialized literature has reported promising data on the use of electronic measurements in the clinical practice, with a high level of accuracy in locating the apical constriction $(3,4)$.

Studies carried out in vitro and in vivo have shown that changes in WL commonly occur during the cleaning and shaping of curved root canals (5-7). Preflaring is an important step in endodontic therapy, especially when dealing with flattened and curved canals. Coronal flaring has been found to facilitate the placement of files into the apical portion of curved root canals (8). Stabholz et al. (9) analyzed the potential effect of preflaring on the tactile sensitivity of operators who attempted to manually locate the apical constriction and found that the procedure could significantly increase the accuracy of the process.

Based on this finding and on the broad use of apical locators in the clinical practice, the present investigation was designed to help find answers to questions not yet completely clarified by the literature: 1) should electronic root canal measurement be carried out before or after cervical flaring? and 2) does cervical flaring have any influence on this type of measurement? The present study evaluated the effect of preflaring on the electronic measurement of WL in mesiobuccal root canals of maxillary molars.

\section{Methodology}

This study was approved by the Research Ethics Committee of the Federal University of Rio Grande do Sul, Porto Alegre, RS, Brazil (No.12/08). Thirty extracted human maxillary molars were radiographed in buccal-palatal direction. Teeth showing previous endodontic manipulation, incomplete root formation, calcification, internal or external resorption or curvature greater than $70^{\circ}$ were excluded from the study. Root canal curvature was determined and recorded following the technique described by Schneider (10). Root canals with curvatures between 20 and 40 degrees were selected.

Crowns were sectioned $5 \mathrm{~mm}$ below the cementoenamel junction, and the mesiobuccal root was separated from others. One stable reference point was marked on the cervical portion of each root to minimize measurement errors.

Root canals were irrigated with $2.5 \%$ sodium hypochlorite (Biodinâmica, Química e Farmacêutica Ltda, Ibiporã, Brazil) and accessed using a size $10 \mathrm{~K}$ file (SybronEndo, Glendora, Glendora, CA, USA).

In order to conduct electronic measurements, roots were embedded in an alginate model (Jeltrate, Dentsply, Petrópolis, RJ, Brazil). Roots were inserted so as to maintain the root portions immersed in alginate, except for the last 3 $\mathrm{mm}$ of the cervical third. Once alginate had set completely, electronic measurements were initiated and carried on without interruptions, in order to conserve alginate humidity conditions.

The labial clip was inserted into the alginate laterally to the tooth being measured. Root canals were irrigated with $1.8 \mathrm{ml}$ of $2.5 \%$ sodium hypochlorite before introduction of the measurement file. Excess irrigating solution was removed, and the canal was left wet.

A size $10 \mathrm{~K}$ file was connected to the Ipex Locator EAL (NSK, Nakanishi, Japan) and gradually introduced until the locator's display and the corresponding acoustic signal indicated that the instrument had reached the apical constriction. Measurements were considered valid if the instrument remained stable for at least 5 seconds. Three measurements were made for each tooth, and teeth with discrepancies in the three measurements were discarded. The instrument was fixed and the silicon stop adjusted to the reference point and cemented to the file with cyanoacrylate. Then, the file was removed, and the first measurement was conducted using a millimeter ruler and a clinical microscope.

All preparations and WL determinations were carried out by the same operator, a board-certified endodontist with experience in the use of EALs.

The intraclass correlation coefficient (ICC) was calculated for quantitative variables and resulted 0.80 , suggesting an adequate correlation between the measurements produced by the examiner.

Silicon stops were placed on all rotary and hand files for use as a reference gauge in determining the depth of canal penetration. After the first measurement, specimens were removed from the alginate model and preflaring was carried out using ProTaper shaping files (Dentsply/Maillefer, Ballaigues, Switzerland), according to manufacturer's instructions. Movement consisted of a brushing motion sequence defined as S1-SX-S1. Recapitulation was performed with a size $10 \mathrm{~K}$ file followed by irrigation with $1 \mathrm{ml}$ of $2.5 \%$ sodium hypochlorite after each instrument change. Subsequently, roots were replaced in the alginate model, and new measurements were conducted. Measurements were compiled and compared using the Student's $t$ test for paired samples.

\section{Results}

The mean length obtained in unflared canals was $15.60 \pm 1.41 \mathrm{~mm}$, and in preflared canals, $15.42 \pm 1.33 \mathrm{~mm}$ (mean difference: 0.18 ). The Student's $t$ test for paired samples did not reveal statistically significant differences in the measurements obtained for preflared and unflared canals $(P<0.05)$ (Table 1$)$. 
Table 1. Comparison between measurements.

\begin{tabular}{ccccccc}
\hline Canals & N & Mean $(\mathrm{mm})$ & $\begin{array}{c}\text { Standard } \\
\text { deviation }\end{array}$ & $\begin{array}{c}\text { Mean } \\
\text { difference* }\end{array}$ & $\boldsymbol{t}$ & $\boldsymbol{P}$ \\
\hline Preflared & 30 & 15.42 & 1.33 & 0.18 & 1.459 & 0.155 \\
Unflared & 30 & 15.60 & 1.41 & & & \\
\hline
\end{tabular}

* Mean difference $=$ Mean differences between values obtained with unflared and preflared canals.

\section{Discussion}

Several studies have addressed the advantages and greater clinical performance of EALs $(3,4)$. The accuracy associated with the latest generation of EALs is directly related to these results. In addition, more recent devices are considerably less sensitive to the influence of external factors, such as humidity, bleeding, presence of metallic restorations, or friction between dentinal walls and the instrument used in WL determination(11-15). As a result, it is currently possible to obtain safer measurements even under non-ideal conditions.

The results of this study revealed a mean difference of $0.18 \mathrm{~mm}$ in electronic WL measurement after cervical flare with the ProTaper system, however without statistically significant differences between preflared and unflared canals. Similarly, Davis et al. (16) reported a decrease in WL after coronal flaring and also after curved canal preparation. WL reduction after cervical preparation with Profile GT was 0.07 $\mathrm{mm}$, compared to $0.22 \mathrm{~mm}$ after canal preparation.

Ibarrola et al. (8) conducted a study to assess whether canal preflaring would improve the efficacy of EALs and found statistical differences between the means obtained in the two groups, with more consistent results associated with the preflared group. Nevertheless, the significant finding reported by those authors can be explained by the fact that the unflared group included three samples with an excessive deviation from the rest of the measurements. Moreover, the authors informed that the clinical significance of their findings might be limited, because measurements in both groups were comparable, with a mean of 0.04 in the preflared group vs. 0.4 in the control group.

WL reduction after cervical flare can probably be explained by elimination of the cervical constriction, i.e., the region in which canal diameter is flattened and narrow (16). In addition, preflaring straightens the curvature to which the instrument is submitted in curved molar roots, resulting in a decreased WL to be covered by the instrument until reaching the apical third.
The nonsignificant changes in WL found in this study after preflaring with rotary nickel-titanium files can probably be explained by the increased capacity of these instruments to remain in a central position in the canal, minimizing canal straightening. This hypothesis is supported by the studies of Thompson \& Dummer (6) and Bryant et al. (7) who reported that nickel-titanium rotary files caused minimal changes to canal configuration.

Flaring of the coronal third of root canals has been recommended by recent techniques. It has been suggested that coronal flaring contributes to a successful performance in subsequent treatment processes, namely preparation, irrigation, and obturation. Coronal flaring has also been shown to help determine the first file to bind at the WL and to establish the correct final diameter required for complete apical enlargement (17-18).

WL determination is an intrinsic part of a treatment setting that often involves cases with necrotic pulp tissue and periapical lesions, in which microorganisms and decomposed organic residues are present in the root canal system. In such cases, inserting an instrument into the apical third without prior preparation may cause the residues to extrude through the apical foramen, with undesirable consequences. Cervical flaring prior to WL determination is therefore essential in such situations.

Independently of the method employed, once WL is determined, it should remain unchanged throughout the treatment regimen, so as to guarantee that root canal preparation and obturation will be conducted within the adequate apical limit.

Based on the findings of this research and on others commented on above, it becomes clear that instrumentation causes changes to the WL of curved canals. However, when only the cervical third is flared with nickel-titanium files, the resulting change in WL becomes irrelevant for the clinical practice. In view of the lack of clinical relevance of the comparisons carried out in the present study, it is possible to conclude that electronic WL measurement can be carried out either before or after cervical flaring with nickel-titanium rotary files.

References 1. Kuttler Y. Microscopic investigation of root apexes. J Am Dent Assoc 1955;50:544-52.

2. Chugal NM, Clive JM, Spångberg LS. Endodontic infection: some biologic and treatment factors associated with outcome. Oral Surg Oral Med Oral Pathol Oral Radiol Endod 2003;96:81-90

3. D'Assunção FLC, Salazar-Silva JR, Bezerra PM. The accuracy of root canal measurements using the Mini Apex Locator and Root ZX-II: an evaluation in vitro. Oral Surg Oral Med Oral Pathol Oral Radiol Endod 2007;104:e50-3. 
4. Shabahang S, Goon WW, Gluskin AH. An in vivo evaluation of Root ZX electronic apex locator. J Endod 1996;1 1:616-8.

5. Al-Omari MAO, Dummer PMH, Newcombe RG. Comparison of six files to prepare simulated root canals. Part 1. Int Endod J 1992;25:57-66.

6. Thompson SA, Dummer PMH. Shaping ability of Profile .04 taper Series 29 rotary nickeltitanium instruments in simulated root canals. Int Endod J 1997;30:1-7.

7. Bryant ST, Thompson SA, Al-Omart MAO, Dummer PMH. Shaping ability of Profile rotary nickel-titanium instruments with ISO sized tips in simulated root canals: Part 1. Int Endod J 1998;31:275-81

8. Ibarrola J, Chapman B, Howard JH, Knowles KI, Ludlow MO. Effect of preflaring on Root ZX apex locators. J Endod 1999;25:625-6.

9. Stabholz A, Rotstein I, Torabinejad M. Effect of preflaring on tactile detection of the apical constriction. J Endod 1995;21:92-4.

10. Schneider SW. A comparison of canal preparations in straight and curved root canals. Oral Surg Oral Med Oral Pathol 1971;32:271-5

1 1. Briseño-Marroquín B, Frajlich S, Goldberg F, Willershausen BW. Influence of instrument size on the accuracy of different apex locators: an in vitro study. J Endod 2008;34:698-702.

12. Ebraim AK, Yoshioka T, Kobayashi C, Suda H. The effects of file size, sodium hypochlorite and blood in the accuracy of Root ZX apex locator in enlarged root canals: an in vitro study. Aust Dent J 2006;51:153-7.

13. Farber JP, Bernstein M. The effect of instrumentation on root canal length measured with an electronic device. J Endod 1983;9:114-5.

14. Jenkins JA, Walker WA 3rd, Schindler WG, Flores CM. An in vitro evaluation of the accuracy of the Root ZX in the presence of various irrigants. J Endod 2001;27:209-11.

15. Pommer $O$, Stamm O, Attin T. Influence of the canal contents on the electrical assisted determination of the length of root canals. J Endod 2002;28:83-5.

16. Davis RD, Marshall JG, Baumgartner JC. Effect of early coronal flaring on working length change in curved canals using rotary nickel-titanium versus stainless steel instruments. J Endod 2002;28:439-42.

17. Contreras MAL, Zinman EH, Kaplan SK. Comparison of the first file that fits at the apex, before and after early flaring. J Endod 2001;27:113-6.

18. Ibelli GS, Barroso JM, Capelli A, Spanó JCE, Pécora JD. Influence of cervical preflaring on apical file size determination in maxillary lateral incisors. Braz Dent J 2007;18:102-6. 